\title{
The East Asian Economy Post-rebalancing: Domestic Demand-led Growth, Social Security, and Inequality
}

\author{
Kosuke Mizuno ${ }^{1}$
}

\begin{abstract}
East Asian, including ASEAN (Association of Southeast Asian Nations), countries have pursued the export-oriented development strategies, attracting foreign direct investment and promoting export-driven growth. However, after the Lehman shock, these countries adopted rebalancing policies from export-driven growth to domestic demand-driven growth. Chinese measures to promote domestic demand since 2008 had succeeded in boosting the economy until 2011 with domestic investments and increase in consumption. Chinese economic growth until 2011-2012 made possible an international commodity boom that resulted in the economic development of Malaysia and Indonesia. However, since 2012, the Chinese economy has been suffering from excess capacity and bad loans, hence ending the international commodity boom. ASEAN countries promptly started rebalancing by cutting back on their reliance on exports and increasing domestic investment and consumption, with variation among the countries. ASEAN countries pursued inclusive policies such as education, medical care, and social security. These policies promoted consumption and investment, helping grow the middle class. However, technological progress, globalization, and market-oriented reforms have also been the driving inequality in many Asian countries in the last two decades, and these forces have changed income distribution through three channels, namely, capital, skill, and spatial bias. Inequality created by conventional development strategies in this region has become the basis for conflicts among the region's different economic strata. Inequality has had the effect of depressing investment-and thus growth-by fueling economic, financial, and political instability.
\end{abstract}

Keywords: East Asian Economy, Rebalancing, Domestic Demand-driven Growth, Inclusive Policy, Inequality

\footnotetext{
${ }^{1}$ Professor of Development Studies at the Center for Southeast Asian Studies (CSEAS), Kyoto University. Japan. Corresponding e-mail: mizuno@cseas.kyoto-u.ac.jp
} 


\section{Kosuke Mizuno}

\section{Introduction}

The global financial crisis, sometimes called the Great Recession triggered by the Lehman shock in 2008, was the worst financial crisis since the Great Depression, involving stock market crashes, credit crunches, housing slumps, and inventory adjustments (Stiglitz, 2010, p. 27). As unemployment rose in the United States, more and more families depleted their savings, lost their homes, and worst of all, lost hope (Krugman, 2012, p. 4). This Great Recession has had deep and debilitating consequences for the American and European economies that are felt until today.

In East Asian countries, the impact of the Lehman shock was not felt as a financial crisis, but as a sudden drop in exports to US and European markets. Before the crisis, more than two-thirds of the region's exports went to markets outside the region, especially in Europe and the United States (Vo, 2012). This paper discusses the implications of the Great Recession on policy making to sustain growth in the East Asian region. The overall theme is the need for "rebalancing," meaning reducing the dependence on western markets and export-led growth. This paper discusses the people's welfare from the viewpoint of social security and inequality.

\section{Background: From the 1997 Asian Financial Crisis to "Rebalancing"}

By the mid-2000s, East Asian economies had recovered from the 1997 Asian financial crisis. In the short term, they had drastically depreciated their currencies. In the longer term they had reduced imports and increased exports, partly as a result of the adjustment in currency values, also by developing production networks and fragmentation of production processes (Hiratsuka, 2006). Inter-Asian trade had grown, especially in terms of parts and materials, although final products still relied on US and European markets. In 2011, three years after the shock, the demand for consumer goods in the developed world (e.g., Europe, Japan, and the United States) remained sluggish as households were saving in order to defray their debts and to rebuild lost wealth (Asian Development Bank, 2011, p. 4). East Asian economies thus began looking around for alternative sources of demand, especially within the region.

The Lehman shock made people conscious of the structure of global imbalance. East Asian countries, with the exception of Vietnam, had been persistently running a 
surplus on their current accounts while the US persistently ran a deficit. ${ }^{2}$ In other words, East Asian countries had high savings rates, while Western countries, especially the United States, had high levels of consumption. However, this trend was unsustainable. Consumption growth in the United States was fed by low-income families taking advantage of easy credit to build up unmanageable levels of debt. ${ }^{3}$ East Asian countries were saving more than they were able to invest. While the initial responses of East Asian governments to the crisis had been Keynesian policies to boost demand, these were only modestly effective because of the structural conditions in the background, and threatened to result in large budget deficits and growing public debt. This was a time to think about policies that would address the structural problems and thus have a longer-term impact.

Within this new perspective, the first priority for East Asian countries was to find alternative markets to compensate for the drop in demand in Western markets. The second priority was to reduce the dependence on exports as a source of growth. The Asian Development Bank (ADB) and the International Monetary Fund (IMF) dubbed this as "rebalancing" the Asian economy. ADB argued that the emerging middle classes of Asia, especially those in China and India, could spearhead the growth of global consumer demand, assuming the role played earlier by the American and European middle classes. At the same time, reducing the dependence on exports as a source of growth implied a growth in domestic demand, which, in turn, required expansion of stable and well-remunerated employment (Asian Development Bank, 2011, p. 4; Kharas \& Gertz, 2010).

The proposed rebalancing represented a major change in direction. Asia's successful emergence over prior decades had been based on a strategy of outwardoriented growth, especially allowing market forces to play a greater role in the economy and encouraging the production of tradable goods. As a result of this strategy, Asia had come to account for over one-fourth of the world economy, ${ }^{4}$ and nearly one-fourth of all the world's exports. But this strategy also had its costs. The nontradable sector, particularly services, had been neglected. External dependence

\footnotetext{
${ }^{2}$ Across the 2000s decade, the current account surplus in Asian countries had averaged nearly $4.5 \%$ of GDP.

${ }^{3}$ In the decade before the crisis, the bottom $80 \%$ of US consumers had been consuming at the level of around $110 \%$ of their incomes (Stiglitz, 2015: 388).

${ }^{4}$ When measured at current exchange rates.
} 


\section{Kosuke Mizuno}

laid economies open to swings in external demand (Arora, Cardarelli eds., 2011, xiii-

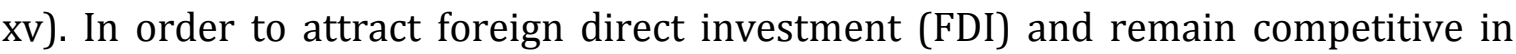
world export markets, firms and governments prioritized productivity while repressing wages, limiting the provision of social security, and ignoring environmental controls (Holliday \& Wilding, 2003; Suehiro, 2008, p. 111-115; Deyo, 1989). This "dangerous obsession" with minimizing labor costs reduced domestic demand and enhanced dependence on exports for growth (Krugman, 1994; Aiginger, 2006). It also increased inequality and damaged the natural environment.

Proposals for rebalancing had three main elements. First, boosting domestic demand through wage- and profit-led policies accompanied with improvement of social security. Stiglitz argued that support for small- and medium-sized enterprises would raise both employment and wage levels, and thus shift the distribution of income in ways that promote more domestic consumption. Enterprises in China retain a large fraction of their income because low wages ensure high profits. Higher labor distribution would have more revenues to finance health, education, and retirement benefits, which would reduce some of the need for high household savings (Stiglitz, 2010, pp. 228-229).

Second, increasing domestic investment, especially in the larger ASEAN countries, where investment had been relatively low since the 1997-1998 Asian financial crisis. Third, reorienting production away from the export sector toward sectors serving domestic markets, including nontradable products and services (Arora \& Cardarelli, 2011, pp. xiii-xv). What were the policies adopted to develop domestic demand-based growth? The major areas were: strengthening social safety nets to reduce the need for precautionary savings and thus release money for consumption, improving infrastructure to encourage more private investment, and deepening of the financial sector to support both private consumption as well as investment by small and large firms. The mix adopted in each country differed, reflecting in part the varied patterns of domestic demand (Arora \& Cardarelli, 2011, pp. xiii-xv).

Several writers have already broached these issues. Hock (2011) discussed the ASEAN countries' policies to manage the crisis, and assumed a brighter outlook of global economy in 2010 and the recovery of ASEAN economies. Ping (2009); Jwa \& Saugyeon (2009) discussed the origin of global financial crisis, and Lim (2009) collected short essays on the global financial crisis. None of these, however, consider 
the long-term implications of faltering growth in the economies of the United States and the European Union (EU) and the need to develop alternative sources of demand to sustain the growth of the East Asian economy.

\section{Current Account Surplus and Savings-over-Investment Characteristics in East} Asian Countries

From the 1970s, large trade surpluses appeared in Japan, and then from the 1980s in Taiwan. After the 1997 Asian financial crisis, however, current account balances went into surplus across East Asia except in a few countries such as Vietnam and Myanmar. Countries are now saving more than they are investing. This is a new situation, a structural change from earlier times when countries in this region invested more than they saved. The increase in current account surpluses was a result of increases in exports. The ratio of exports to GDP increased rapidly in many countries immediately after the Asian financial crisis, primarily as a result of the sudden devaluation of currencies. ${ }^{5}$ In Malaysia, for example, the export-GDP ratio jumped from $76 \%$ in 1996 to $106 \%$ in 1999 , and stayed in the range of $92-105 \%$ over $2000-$ 2007. More dramatically, Thailand's export-GDP ratio almost doubled from $29 \%$ in 1996 to $55 \%$ in 2000 , and remained in the range of $52-62 \%$ over $2000-2010$. In the Philippines and Indonesia, the export-GDP ratio initially surged, but then decreased somewhat, in the case of Indonesia from $52 \%$ in 1999 to a range of $27-30 \%$ over 2002-2008. China's currency was not affected in the 1997 crisis, but had been drastically devalued earlier in 1981-86 and again in $1994 .{ }^{6}$

With the increase in exports, interdependence within East Asian countries increased (Sugihara, 2005). The proportion of total exports destined for markets within East Asia rose from $42.3 \%$ in 2000 to $46.9 \%$ in 2007 . There is some variation among different types of goods. In 2007, 57.6\% of all exports of parts and accessories were destined for markets within the region, but only $20.7 \%$ of consumer goods (Kuroiwa et al., 2009). Inomata et al., (2012) discuss the tripolar trade through China. China exports final consumption goods to the United States while importing parts and

\footnotetext{
5 Taking the dollar exchange rate in 1996 as 100, the rate in Indonesia dropped to 23.4 in 1998 , and remained in the range of 22-27 over 2001-2010; the rate in South Korea to 57.4 in 1998 then appreciated somewhat to a range of 62-84 over 2000-2010; in Malaysia, the rate dropped to 66.2 in then recovered to 78.1 in 2010.

${ }^{6}$ Assuming the value in 1981 at 100, the rate was 19.8 in 1994 and 25.2 in 2010 . The low level of the Chinese currency may have contributed to the Asian financial crisis (McKinnon et al., 2009).
} 


\section{Kosuke Mizuno}

accessories from other East Asian countries. As a result, Japan, South Korea, and other East Asian countries have a trade surplus with China.

The high ratio of current account surplus is related to the savings-investments gap. China has an especially high ratio of savings to GDP, particularly corporate savings, as a result of the repressed financial system dominated by state banks, subsidies on land and energy, monopolies that deliver high profits, and the incentive to reinvest profits in a fast-growing economy. State-owned enterprises did not have to pay dividends until recently. The ratio of household savings to disposable income has also increased, though the share of household savings in total savings has declined due to the rise in corporate savings. The pattern in India is similar.

The high rate of household savings is partly explained by the demographic structure and the U-shaped pattern in which younger and older generations have a high propensity to save. However, another factor driving high savings is the increasingly heavy burden of education and health expenditure. The development of financial markets could enable households to borrow against future income, as well as allowing households to earn more on their savings through portfolio diversification. Improvements in the social safety net would pool the risks associated with income shocks and health expenditures. ${ }^{7}$ To promote rebalanced growth, especially domestic demand growth, Prasad (2009, pp. 2-28) recommends a policy mix that includes improvements in the social safety net and development of the financial market to give more people access to opportunities for credit and savings.

\section{Stagnation in Investment and Financial Reform in East Asian Countries}

In most East Asian countries, investment (gross domestic capital formation) decreased drastically after the Asian financial crisis in 1997. In Thailand, for example, the ratio of investment to GDP fell from an average of 41.2\% over 1991-1996 to $25.7 \%$ over 2000-2005, while the ratio of savings to GDP fell much less (from $36.0 \%$ to $31.7 \%$ ). As a result, the savings-investment gap changed from $-4.2 \%$ over $1991-1996$ to $+6.0 \%$ over $2000-2005$. This decreasing trend in investment was found in all major countries of the region except China and Vietnam. ${ }^{8}$

\footnotetext{
${ }^{7}$ In China and Taiwan, households where the head is beyond retirement age have high rates of saving, which could be reduced if health and social security systems were more reliable.

${ }^{8}$ In South Korean the ratio of investment-to-GDP decreased from 37.4\% over 1991-1996 to $29.7 \%$ over 2000-2005, and in Malaysian investment from $39.8 \%$ to $23.6 \%$ over the same time periods.
} 
Although special reasons for this decline can be found in individual countries, ${ }^{9}$ the shared trend demands a common explanation. The financial system in East Asian countries was roundly blamed for the Asian financial crisis. Weak banking surveillance and inadequate legal provisions had allowed financial institutions to accumulate high levels of nonperforming loans. As part of its stabilization policies, the IMF demanded a variety of financial-sector reforms including bank closures, management restructuring, disposal of bad loans, better bankruptcy laws, tighter provisions for management of credit, and reviews of accounting and audit procedures. The IMF's approach was guided by the Anglo-American model of corporate finance, and aimed to change the financing structure in East Asian countries from indirect financing through banks to direct financing through stock markets. Fukagawa (2004) has shown that this attempt failed.

The number of companies listed on the stock market in East Asian countries has remained rather limited. The reforms helped companies avoid drastic expansion and sudden bankruptcy, but corporate governance is not a necessary and sufficient condition. Mieno (2009) has shown that corporates in Southeast Asia now depend heavily on self-financing for growth capital rather than on loans or capital issues. Attempts to develop a bond market have been rather limited, and have been skewed toward nonmanufacturing and finance, which are geared mainly to domestic economic activities. Commercial banks have restructured themselves to concentrate on financial services and personal consumption loans, and provide little capital for manufacturing. What can be done to raise the rate of investment, especially in the manufacturing and agricultural sectors? How do economies increase domestic investments?

\section{Private consumption}

According to the growth accounting by Prasad (2009, pp. 2-28), in 15 countries of East, Southeast, and South Asia, private consumption accounted for $57.2 \%$ of GDP in 2008 , and contributed $60.3 \%$ of GDP growth over 2000-2008, while net exports accounted for $4.3 \%$ of GDP in 2008, and contributed 7.6\% of GDP growth over 20002008. However, the level of consumption in East Asian countries is typically lower

\footnotetext{
9 For example, Indonesia underwent "deindustrialization," and Malaysia diverted investments overseas.
} 


\section{Kosuke Mizuno}

than that in Western countries. In 2010, the ratio of household consumption to GDP was in the range of $0.5-0.6$ in Thailand, Malaysia, and Indonesia compared to 0.84 in UK, 0.86 in the US, and 0.76 in Germany. China is significantly lower at 0.35 .

China achieved high levels of growth despite a very low rate of consumption because its final products were exported to US and European markets (Tang, 2005). High savings means low consumption. Kojima (2008, pp. 45-47) found two reasons behind China's low consumption rate. First, the consumption rate in rural areas is extremely low. Although $56.1 \%$ of the total population lives in rural areas, rural consumption contributed only $9.5 \%$ to GDP in 2006 . Second, the labor allocation rate is low at $41.4 \%$ in 2005 (hence the high rate of corporate savings).

The Chinese government now wants the country to become not only the factory of the world, but also the market for the world. This will require a major rebalancing of savings and consumption. Can China and India replace western markets as the source of demand growth for the final products of other Asian economies? At present, Chinese consumption is still too weak to perform this role. The recent growth of exports from rest-of-Asia to China have been largely inputs and components for goods manufactured in China for export to western markets. In India, as Bhaduri shows, the rapidly growing income of the top $15 \%$ of the population creates demand for a narrow range of goods that cannot be produced by small producers in the unorganized sector or by village artisans. Thus, the majority are not only ruled out from the market as consumers because they do not have adequate purchasing power, but are also excluded as producers because of the sophisticated nature of the demand. Demand stagnation due to growing inequality is countered, paradoxically, by increasing inequality.

East Asian countries cannot rely heavily on the Chinese and Indian markets for the final goods at least in coming years, hence the need to enhance demand in each individual country, or in the regions, including China and India, on their own through various ways such as social security, improvement of labor allocation, and job growth through the development of small and medium enterprises that create a strong middle class while reducing poverty.

The rise of the Asian middle class has already hugely expanded markets for consumer goods in recent years. Sales of consumer durables such as refrigerator, TV sets, mobile phones, and automobiles have expanded significantly in virtually all 
countries of the region. China is now the world's largest auto market and India the fastest growing. Since the middle class in Asia is poorer-and so far spends much less-than the Western middle class, firms have had to develop affordable new products and services targeted to this group of consumers. (Asian Development Bank, 2010, p. 48)

\section{Social security in East Asian countries}

Social security or welfare policies in this region have been discussed extensively. Jones used the term "oikonomic welfare states" for countries such as Hong Kong, Taiwan, Singapore, and South Korea. By this she meant that these states prioritize economic growth as a policy goal and rely on the family to be the main provider of welfare. They emphasize duty and obligation, see order and social stability as the very basis of welfare, have little interest in social justice and social rights, and are equivocal on the need for Western-style politics (Jones, 1990). She listed the main characteristics of Confucian welfare states as "conservative corporatism without [Western-style] worker participation; subsidiarity without the Church; solidarity without equity; laissez-faire without liberalism; an alternative expression might be 'household economy' welfare states-run in the style of a would-be traditional Confucian extended family" (Jones, 1993, p. 214). White \& Goodman (1998) used the terms "East Asian Welfare Model" and "productivist welfare capitalism" to describe the explicit subordination of social policy to economic ends, while Holliday \& Wilding (2003) titled their book on the subject as Welfare Capitalism in East Asia.

These productivist welfare systems give first priority to education, and second to medical care. To prepare for old age, people are encouraged to save in both informal and formal pension systems, and the state draws on these funds for development programs in some countries. Where states do make provision for pensions, they give priority to civil servants and soldiers, and exclude those in the informal sector (Rames \& Asher, 2000). The limited extent of these social security systems induce people to save more as provision against risks.

However, as democratization proceeds, pressures emerge for fuller state provisions. Suehiro (2006) argues that democratization since the late 1980s was followed by rising interest in quality of life among citizens, widespread concern over social safety nets and social protection policies in the aftermath of the 1997 Asian 


\section{Kosuke Mizuno}

financial crisis, and a specific concern over provision for old age as birth rates decline and the proportion of elderly in the population increases. These factors have pressed East Asian governments to forge new social welfare schemes. We can see the stages in social security among East Asian countries in Table 1.

Table 1. Social Security System in East Asia

\begin{tabular}{|c|c|c|c|c|c|c|}
\hline & \multicolumn{2}{|c|}{ Social Security System } & \multirow{2}{*}{$\begin{array}{c}\text { Economic } \\
\text { Development } \\
\text { Stage }\end{array}$} & \multirow{2}{*}{$\begin{array}{l}\text { Industrial } \\
\text { Structure }\end{array}$} & \multicolumn{2}{|c|}{ Demographic Transition } \\
\hline & Current System & Challenges & & & $\begin{array}{c}\text { Population } \\
\text { Structure }\end{array}$ & Urbanization \\
\hline $\begin{array}{l}\text { Third Phase } \\
\text { (Japan, Korea, Taiwan, } \\
\text { Hong Kong, } \\
\text { Singapore) }\end{array}$ & $\begin{array}{l}\text { Universal } \\
\text { system }\end{array}$ & $\begin{array}{c}\text { To reform with } \\
\text { population ageing }\end{array}$ & High income & $\begin{array}{l}\text { Service-led } \\
\text { structure }\end{array}$ & $\begin{array}{c}\text { Accelerating } \\
\text { population ageing }\end{array}$ & Urban society \\
\hline $\begin{array}{l}\text { Second Phase } \\
\text { (Malaysia, Thailand, } \\
\text { Philippines, Indonesia, } \\
\text { China) }\end{array}$ & $\begin{array}{c}\text { System covering } \\
\text { public sectors } \\
\text { and employee of } \\
\text { private } \\
\text { company. }\end{array}$ & $\begin{array}{c}\text { To establish } \\
\text { universal system } \\
\text { covering informal } \\
\text { sector and rural } \\
\text { people }\end{array}$ & Middle income & $\begin{array}{l}\text { Manufacture- } \\
\text { led structure }\end{array}$ & $\begin{array}{l}\text { Rapid Declining of } \\
\text { Fertility Rate }\end{array}$ & $\begin{array}{c}\text { Transition from } \\
\text { rural society to } \\
\text { urban society }\end{array}$ \\
\hline $\begin{array}{l}\text { First Phase } \\
\text { (Vietnam, Laos, } \\
\text { Cambodia, Myanmar) }\end{array}$ & \begin{tabular}{|} 
System covering \\
only public \\
sector
\end{tabular} & $\begin{array}{c}\text { To expand system } \\
\text { covering employee of } \\
\text { private company }\end{array}$ & Low income & $\begin{array}{c}\text { Agriculture-led } \\
\text { structure }\end{array}$ & $\begin{array}{l}\text { Starting falling of } \\
\text { fertility rate }\end{array}$ & Rural society \\
\hline
\end{tabular}

Source: Based on Hiroi \& Komamura (Eds.). (2003, p. 11-12)

Oizumi (2010) has correlated these phases with the demographic transition. In the second phase of the process outlined in Table 1, the social security system is expanded, as recently seen in middle-income ASEAN countries such as Thailand, Malaysia, Indonesia, and the Philippines. During this phase, the birth rate rapidly declines, raising the proportion of those of productive age (15-64) in the total population, thus boosting economic growth through the so-called demographic dividend. These countries usually already have social security systems covering employees in the public sector and the formal part of the private sector. The challenge, then, is how to expand these social security systems to include self-employed workers, the informal sector in urban areas, and independent farmers in rural areas, and thus establish a universal social security system (Oizumi, 2010).

\section{Rebalancing in Asia}

\section{China's Ten Measures}

In November 2008, the Chinese government put forward the "Ten Important Measures for Promoting Domestic Demand and Economic Growth" and resolved to 
spend 4 trillion Yuan on economic stimulus measures by the end of 2010. At the same time, the government stimulated consumption through price subsidies, consumer credit, and measures to improve distribution of targeted products (Tang, 2005). As a result of this huge investment and loosening up of the financial market, the Chinese economy boomed from the third quarter of 2008 until the end of 2011. The terms of trade became the favorite for primary commodity-exporting countries such as Russia, Australia, Indonesia, and Brazil. It was said that where the Chinese sold goods, the price decreased, and where the Chinese bought goods, the price went up (Kan, 2014, pp. 184-202).

Since 2008 China resolved to move away from growth based on exports and investment toward growth based on domestic demand and consumption. The ratio of exports to GDP fell from $34.9 \%$ in 2007 to $21.7 \%$ in 2014, and the current account surplus dropped from $10.1 \%$ to $2.1 \%$ over the same period. This change, however, was related to the stagnation in the US and EU economies in those years. The Asian Development Bank (2015, p. 130) argued that "no further progress was made toward replacing investment-driven growth with growth driven by consumption." Investment contributed $4.2 \%$ points to GDP growth in 2013, up from 3.8\% in 2012, and consumption contributed 3.8\% points, down from 4.1\% (Asian Development Bank, 2015, p. 130).

Chinese policy is shaped by its past success. Since the 1990s state-owned companies and local governments have played an important role in investment and manufacturing (especially in heavy industries such as steel), real estate and housing, and transportation, resulting in double-digit growth in many years (Kojima, 2008: 4057). After the Lehman shock, the same strategy of investment-driven development policy along with loosening of the monetary market succeeded in sustaining the trajectory of economic growth. However, two major problems arose. First, excess capacity emerged. In 2013, excess capacity was widespread throughout the manufacturing sector, affecting 19 of 29 subsectors that together shared $87 \%$ of sector assets and 84\% of profits (Asian Development Bank, 2015, p. 143). Second, bad loans in the financial system increased, especially among borrowers from trust funds. Many of the culprits were real estate developers and companies in industries with excess capacity (ADB, 2014, p. 127). Growth decelerated from 2012 onward. 


\section{Kosuke Mizuno}

Despite this slowdown, China shows some positive signs. China's GDP doubled between 2009 and 2015, contributing about a third of global growth. Rebalancing policies have had some effect. In 2015, the service sector contributed $3.7 \%$ points to China's total GDP growth, while industry contributed $2.8 \%$, and agriculture $0.3 \%$. Within industry, consumer-oriented manufacturing outperformed heavy industry, which continued to suffer from excess capacity, spillover from an ailing housing sector, and lower commodity prices. On the demand side, consumption was the main growth engine, contributing $4.6 \%$ points to GDP, up from 3.7\% in 2014, while investment contributed $2.5 \%$ points, down from $3.4 \%$ in 2014 , and the contribution of net exports turned negative (ADB, 2016: 124-125). Rebalancing from export-oriented development to domestic demand is in process.

\section{US and EU Economies}

The US and EU economies have not fully recovered. In 2015, some eight years after the Great Recession and almost seven years after the collapse of Lehman Brothers, median incomes in the United States are still below the level attained a quarter-century ago. Wages in many European countries are below the level at the start of the crisis (Stiglitz, 2015, pp. 377, 415). In June 2016, unemployment stood at 10.2\% in the Euro area, $20.1 \%$ in Spain, and $4.7 \%$ in the United States (The Economist, 11-17 June 2016). The US economy has recovered somewhat, but consumption is too weak to drive the world economy. The US and European economies have not been creating jobs, and stagnant incomes mean stagnant demand (Stiglitz, 2015, pp. 377, 415).

Since the 2008 crisis, the global economy has drifted. Lower international prices for oil and other commodities were supposed to be a boon to most economies, but the benefits have been slow to come while the shock to commodity-dependent emerging economies has been immediate. Less-than-robust recovery in the industrial economies and slowing growth in emerging markets weigh down on growth prospects everywhere. Volatility in global financial markets that stem from weakness in emerging markets and monetary tightening in the United States is deepening the uncertainty stirred by the global slowdown (Asian Development Bank, 2016, p. 3). 


\section{Rebalancing in Southeast Asian Countries}

The high rate of growth in China triggered a commodity boom with a positive impact on many Southeast Asian countries, especially Indonesia and Malaysia. Since 2012, however, the slackening of China's growth and the fall of commodity prices have had a negative impact on the region. Dependence on exports has shown some signs of decline. In Malaysia, the export-GDP ratio decreased from $102.8 \%$ in 2006 to $61.4 \%$ in 2014. In other major Southeast countries the declines were smaller but significant. Between 2007 and 2014, the export-GDP ratio fell from $61.1 \%$ to 55.5\% in Thailand, $27.4 \%$ to $19.7 \%$ in Indonesia, and $34.4 \%$ to $21.7 \%$ in the Philippines. Current account surpluses also decreased. ${ }^{10}$ Only in South Korea did the current account surplus increase from $2.1 \%$ in 2007 to $6.3 \%$ in 2014.

Domestic demand, especially investment, increased after the Lehman shock. Between 2007 and 2014, the ratio of gross capital formation to GDP ratio increased from $21.6 \%$ to $26.0 \%$ in Malaysia, from $24.9 \%$ to $34.7 \%$ in Indonesia and from $16.9 \%$ to $20.5 \%$ in the Philippines. Only Thailand showed a decrease, from $25.4 \%$ in 2007 to $24.6 \%$ in 2014. Consumption in Malaysia increased from $45.6 \%$ in 2007 to $52.3 \%$ in 2014. Rebalancing was under way in Southeast Asian countries to some extent.

In Indonesia, growth is still driven largely by commodities, especially exports of palm oil and coal, but domestic demand has contributed, especially private consumption, as well as nontradable goods production on the supply side. In 2015 GDP recorded $4.9 \%$ growth even though commodity prices fell, in contrast to other commodity-exporting countries such as Russia and Brazil, where GDP shrank by $-1.2 \%$ and $-5.4 \%$, respectively (Bank Indonesia, 2016). Mizuno (2016) has discussed the impact of the commodity boom on the Indonesian economy, and the role of consumption or nontradable goods production.

\section{Inequality in East Asia}

In the last two decades, especially after 2000, inequality has become a serious issue in Asia. Countries such as China, South Korea, and Indonesia where inequality was relatively low at the beginning of 1990s saw sharp rises in the Gini ratio. ${ }^{11}$ At the

\footnotetext{
10 Between 2007 and 2014, the current account surplus decline from 15.9\% to 4.3\% in Malaysia, from $6.3 \%$ to $3.2 \%$ in Thailand, from $2.4 \%$ to $-2.9 \%$ in Indonesia, and from $4.9 \%$ to $2.1 \%$ in the Philippines. 11 In China from 32.4 in 1990 to 43.4 in 2008, in South Korea from 24.5 in 1992 to 28.9 in 2010, and in Indonesia from 29.2 in 1990 to 38.9 in 2011.
} 


\section{Kosuke Mizuno}

same time, countries where the Gini ratio was already high at the beginning of $1990 \mathrm{~s}$ either showed no decline (Malaysia and the Philippines) or only a modest drop (Thailand) (Asian Development Bank, 2012, p. 47). ${ }^{12}$ Inequality causes many problems. For one, it hampers poverty reduction. ADB has shown that the achieved declines in the poverty headcount rate were significantly lower than would have been achieved if the inequality was less severe. For example, extreme poverty fell to $13.1 \%$ in China in 2008, but would have fallen further to $4.9 \%$ if the effects of rising inequality were removed (Asian Development Bank 2012, p. 41).

Economists once argued that inequality had a positive on growth by creating incentives for hard work and enterprise. That judgment is now under challenge. ADB has shown that long-term growth in an economy can be broken down into phases or "growth spells," in each of which growth accelerates to a higher rate and then falls again (Asian Development Bank, 2012, p. 43). The acceleration can be achieved by a set of conventional reforms, such as liberation of trade or finance, which leads to a burst of investment and output growth. Sustaining this growth is more difficult, and generally requires institutional changes (Rodrik, 2005). Ultimately, the long-term rate of growth depends on how long these growth spells are sustained. Berg, Ostry, \& Zettelmeyer (2008) examined the impact of various factors on the duration of growth spells. They showed that income distribution was as one of the most important factors affecting the duration. A 10-percentile decrease in inequality increases the expected length of a growth spell by $50 \%$. They conclude that inequality is a more robust predictor of growth duration than many variables widely understood to be central to growth. The International Monetary Fund (2015) argues that inequality depresses investment and thus growth by fueling economic, financial, and political instability.

A 2011 study by the Organization for Economic Cooperation and Development (OECD) identified various factors contributing to rising inequality, such as increased financial integration and technological change; increased imports from low-income countries, reducing employment prospects for less skilled workers; changes in labor market policies that tend to reduce income and benefits for less skilled workers; increasing prevalence of part-time work; greater numbers of single-headed households; and increasing income shares for capital, benefiting rich households.

\footnotetext{
12 In Malaysia from 47.7 in 1992 to 46.2 in 2009, in Thailand from 45.3 in 1990 to 40.0 in 2009, and in the Philippines from $43.8 \%$ in 1991 to 43.0 in 2009.
} 
ADB argues that technological progress, globalization, and market-oriented reform - the key drivers of Asia's rapid growth — are the basic forces behind the rising inequality in many Asian countries in the last two decades, and these forces have changed income distribution through three channels, namely, capital, skill, and spatial bias. The bias toward physical capital reduces labor's share of national income. Spatial disparities are becoming more acute: locations with superior infrastructure, market access, and scale economies - such as urban centers and coastal areas-are better able to benefit from changing circumstances (Asian Development Bank, 2012, p. 73).

In addition to these, other studies discuss the role of the labor market and noneconomic factors on increasing inequality. The International Monetary Fund (2015) finds that a decline in organized labor institutions and the resultant easing of labor markets is associated with rising market inequality because labor market flexibility benefits the rich and reduces the bargaining power of low-income workers. The IMF also finds that government policies can contribute to greater or lower equality. From Piketty's study (2014), investment income tends to grow faster than GDP and thus the trends toward inequality of wealth have implications on income inequality and its sustainability. Wealth can be deployed to acquire the political power needed to protect and even intensify the concentration of wealth.

The conventional strategy of export-oriented industrialization pursued in East Asian countries, especially under authoritarian regimes, tends to promote inequality through various paths including liberalization of the finance sector and trade regime, and labor controls that suppress wages and increase the share of capital in income.

Reforms following the Asian financial crisis and the structural adjustment policy that had been pursued by the World Bank, IMF, and ADB also contributed to the worsening of income inequality through measures such as the abolition of subsidies for smallscale businesses and agricultures. In the Philippines, for example, the removal of subsidies for irrigation created an environment in which rich farmers who invested in individual pump irrigation prospered at the expense of the poor ones (Hayami \& Kikuchi, 2000).

Pasuk \& Pongthep (2016) discuss the factors driving inequality in Thailand and its political consequences. Policy bias in favor of wealth accumulation among the few and a spatial bias in Thailand's development have seriously divided the society, leading to conflict between a largely rural mass and the urban elite and middle class. 


\section{Kosuke Mizuno}

The rural mass has a numerical majority that delivers victory at elections, but their opponents wield great informal power and are able to call on the army to remove their opponents by coup, as happened in 2006 and 2014. This political wrangling, with deep roots in inequality, has depressed the rate of economic growth below the regional average. Takamasu (2012) discusses the stagnation of the Japanese economy from the viewpoint of inequality. The prevalence of part-time or irregular workers due to the easing of labor market regulation has dented the conventional Japanese lifetime employment/seniority promotion system, which had been hailed by the OECD as the reason for the strength of the Japanese economy in the 1950s and 1960s.

Inequality has not only created political conflict but also shaped attitudes toward the forces of globalization that lie behind rising inequality, especially the free trade regime, financial liberalization, foreign investment, labor migration, and information technology (Bhalla, 1998; Peterson, 2003). Criticism and opposition have come not only from the right wing, in the form of racism and chauvinism directed against immigrant labor (Doty, 2003), but also from the left wing in campaigns against capital liberalization, free trade regime, and flexible employment. Jong-Woo Lee criticizes the US financial policies based on monetarism and excessive financial deregulation, particularly since the repeal of the Glass-Steagall Act in 1999. The monetarist policy promoted unequal conditions among Americans, enlarging the financial sector while reducing the competitiveness of the US manufacturing sector. Britain's exit from the EU decided by the referendum in 2016 is a right-wing/populistic response (Oliver, 2016) to the issue of immigration especially triggered by the Syrian crisis and inequality. Further, the election of Donald Trump as US president in November 2016 is the result of the right-wing response to immigration and inequality promoted for quite some time now by the policy of globalization and free trade.

\section{Conclusion}

East Asian, including ASEAN, countries have pursued export-oriented development strategies, attracting the foreign direct investment, and promoting export-driven growth. However, after the Lehman shock, these countries adopted rebalancing policies from export-driven growth to domestic demand-driven growth. Stagnation of the US, EU, and Japanese economies have kept these countries from continuing the conventional policy. Chinese government measures to promote 
domestic demand since 2008 had worked to boost the economy until 2011 with domestic investments and increase in consumption. Chinese economic growth until 2011-2012 gave rise to an international commodity boom that resulted in economic development in Malaysia and Indonesia. However, since 2012 the Chinese economy has suffered from excess capacity and bad loans, thus putting a damper on the international commodity boom.

ASEAN countries have begun rebalancing by decreasing export reliance and increasing domestic investment and consumption, with variation among the countries. ASEAN countries have pursued inclusive policies such as education, medical care, and social security to drive consumption and investment, and promote the growth of the middle class. But technological progress, globalization, and marketoriented reform - the key drivers of Asia's rapid growth-have also been the basic forces behind the rising inequality in many Asian countries in the last two decades, and these forces have changed income distribution through three channels, namely, capital, skill, and spatial bias. Inequality created by conventional development strategies in this region has become the basis of conflicts among the region's economic strata. Moreover, inequality in the region has depressed investment-and thus growth-by fueling economic, financial, and political instability. Right-wing response to the inequality and immigration triggered big waves of political change in the UK and US in 2016-a trend that could well continue in European countries in 2017.

\section{References}

Aiginger, K. (2006). Competitiveness: From a Dangerous Obsession to a Welfare Creating Ability with Positive Externalities. Journal of Industry, Competition and Trade, 6(2), 161-177.

Arora, V., \& Cardarelli. R (Eds.). (2011). Rebalancing Growth in Asia, Economic Dimentions for China, Washington D.C.: International Monetary Fund.

Asian Development Bank. (2010). ADB Key Indicator for Asia and Pacific 2010. Mandaluyong City: Asian Development Bank. . (2011). Key Indicators for Asian and Pacific 2011. Manila: Asian Development Bank. . (2014). Asian Development Outlook 2014 Fiscal Policies for Inclusive Growth: Mandaluyong City: Asian Development Bank. 
(2015). Asian Development Outlook 2015 Financing Asia's Future Growth.

Mandaluyong City: Asian Development Bank. . (2016). Asian Development Outlook 2016 Asia's Potential Growth. Mandaluyong City: Asian Development Bank.

Bank Indonesia. (2016) Laporan Perekonomian Indonesia Tahun 2015. Jakarta: Bank Indonesia.

Berg, A., Ostry, J. D., \& Zettelmeyer, J. (2008.). What Makes Growth Sustained? IMF Working Paper 08 (59). Washington, D.C.: International Monetary Fund.

Bhalla, A. S. (Ed.). (1998). Globalization, Growth and Marginalization, London, Macmillan, New York: ST. Martin, Ottawa: International Development Research Center.

Deyo, F. (Ed.). (1989). The Political Economy of the New Asian Industrialism. Ithaca: Cornell University Press

Doty, R. L. (2003). Anti-Immigrantism in Western Democracies Statecraft, Desire, and the Politics of Exclusion. London: Routledge.

Fukagawa, Y. (2004). Governance Reform of Family Business and East Asian Economic Cooperation. In Urata, S (Ed.), The Age of Asian FTA. Tokyo: Nihon Keizai Shinbunsha.

Hayami, Y., \& Masao, K. (2000). A Rice Village Saga: Three Decades of Green Revolution in The Philippines. Basingstoke: Macmillan.

Hiratsuka, D. (Ed.). (2006). East Asia's De Facto Economic Integration. New York: Palgrave Macmillan.

Hiroi \& Komamura (Eds.). (2003). Ajja no Shakai Hoko (Social Security in Asia). Tokyo: University of Tokyo Publications.

Hock, S. S. (Ed.). (2011). Managing Economic Crisis in Southeast Asia. Singapore: Institute of Southeast Asian Studies.

Holliday, I., \& Wilding, P. (2003). Welfare Capitalism in East Asia, Social Policy in the Tiger Economies. New York: Palgrave Macmillan.

International Monetary Fund. (2015). Causes and Consequences of Income Inequality: A Global Perspective. Paper prepared by Era Dabla-Norris et al., June.

Jones, C. (1990). Hong Kong, Singapore, South Korea and Taiwan: Oikonomic Welfare States, Government and Oppositions, 25 (4), 446-62. 
(1993). The Pacific Challenges. In Jones, C. (Ed.), New Perspectives on the Welfare State in Europe. London: Routledge.

Jwa, S. H., \& Saugyeon, H. (2009). A New Interpretation of the Origins of the Subprime Mortgage Crisis, the Failure of Anti-market Government Intervention. Beijing Forum 2009, the Harmony of Civilizations and Prosperity for All-Looking Beyond the Crisis to a Harmonious Future, Collection of Papers and Abstracts of Panel Sessions, Financial Crisis: Challenges and Responses, Beijing Forum Organizing Committee.

Kan, S. (2014). The Economic Perspectives, whether to Overcome the 'Two Trap'. In Akio, T. et al. (Eds.), Lectures on Modern China for People. Tokyo: University of Tokyo Press (in Japanese).

Kharas, H., \& Gertz, G. (2010). The New Global Middle Class: A Cross-Over from West to East. In Cheng, Li, (Ed.), China's Emerging Middle Class: Beyond Economic Transformation. Washington, D.C.: Brookings Institution Press.

Kojima, R. (2008) Hiper Growth and Structural Contradictions. In Nazrul, I., \& Reiitsu, K. (Eds.), Resurgent China: Issues for the Future. Tokyo, Keiso Shobo (in Japanese).

Krugman, P. (1994). Competitiveness: A Dangerous Obsession. Foreign Affairs, 73 (2). . (2012). End This Depression Now. New York: W.W. Norton \& Company.

Kuroiwa, I., Hirosi, K., \& Hajime, S. (2009). The Triangular Trade. In Satoshi, I., \& Yoko, U. (Eds.), Asian Beyond the Crisis, Vision from International Input-Output Analysis. Chiba, Institute of Developing Economies.

Lim, C. (Ed.). (2009). Globalization and Financial Crisis. Singapore: NUS Business School.

Mieno, F. (2009, February 23-24). Foreign Ownership, Listed Status and Financial System in East Asia: Evidence from Thailand and Malaysia. Paper presented at Final symposium of the JSPS-NRCT Core University Program the Making of East Asia: from both Macro and Micro Perspectives, CSEAS, Kyoto University.

Mizuno. K. (2016, November 5-6). The Indonesian Economy Post-Lehman Shock: Some Results of a Macroeconomic Model Simulation. Paper presented at the $15^{\text {th }}$ International Convention of East Asian Economic Association, Sustainable and Inclusive Development in Asia and Global Economy, Bandung. 


\section{Kosuke Mizuno}

Oizumi, K. (2010). Challenges in the Establishment of Universal Social Security Systems in ASEAN, from the perspectives of Demographic Dynamics and the Japanese Experience. Paper presented at Analyzing Global Financial Crisis and East Asia; Twelve Years Change Since the 1997 Economic Crisis and Ideas for a New East Asian Economic Model, in First Joint International Workshop of the JSPS Asian Core Program, CSEAS Kyoto University, Japan.

Oliver, C. (2016). Unleashing Demons: The Inside Story of Brexit. London: Hodder \& Stoughton.

Pasuk, P., \& Pornthep, B. (2016). Thailand: Rebalancing for Growth by Muddle through Plus. (forthcoming).

Peterson, V., \& Spole. (2003). A Critical Rewriting of Global Political Economy, Integrating Reproductive, Productive and Virtual Economies. London: Routledge.

Ping, C. (2009). The Efficient Market Delusion and the Viable Market Evolution, Beijing Forum 2009, The Harmony of Civilizations and Prosperity for All-Looking Beyond the Crisis to a Harmonious Future, Collection of Papers and Abstracts of Panel Sessions, Financial Crisis: Challenges and Responses, Beijing Forum Organizing Committee.

Prasad, E. S. (2009). Rebalancing Growth in Asia. Working Paper 15169, NBER Working Paper Series, Cambridge: National Bureau of Economic Research.

Rames, M., \& Asher, M.G. (2000). Welfare Capitalism in Southeast Asia: Social Security, Health and Education Policies. New York: Palgrave.

Rodrik, D. (2005). Growth Strategies. In Aghion, P.,\& Durlauf. S. (Eds.), Handbook of Economic Growth. North-Holland.

Suehiro, A. (Ed.). (2006) Higashi azia no fukusi sisutemu no yukue: kigyou-nai fukushi to kookka no shakai-hoshou-seido: ronnten no seiri to dehta-shuu (The Direction of the East Asian Social Welfare System: Enterprise-based Welfare and Statebased Social Security System; Points of Contents and Aggregated Data), Institute of Social Science, University of Tokyo (in Japanese).

.(2008). Catch-up Industrialization, the Trajectory and Prospects of East Asian Economies. Singapore \& Kyoto: NUS Press \& Kyoto University Press.

Sugihara, K. (2005). Japan, China, and the Growth of the Asian International Economy 1850-1949. New York: Oxford University Press. 
Stiglitz, J. E. (2015). The Great Divided Unequal Societies and What We Can Do About Them. New York: W.W. Norton \& Company. . (2012). The Price of Inequality, How Today's Divided Society Endanger Our Future. New York: W.W. Norton \& Company. .(2010). Freefall, America, Free Markets, and the Sinking of the World Economy with a New Afterward. New York: W.W. Norton \& Company.

Takamasu, A. (2012, March 13). Lapan's Dilemma: Why has Japan's Economy been Stagnating since the 1990s? Paper presented at seminar After the Global Financial Crisis in East Asia; Toward a New Model of East Asian Economy Center for Southeast Asian Studies, Kyoto University.

Tang, C. (2005). Savings and Finance in China. Tokyo: Keio University Press (in Japanese).

Vo, T. T. (2012, March 13). Beyond the Global Financial Crisis: Perspectives from the global Economy, East Asia, and Vietnam. Paper presented at Seminar After the Global Financial Crisis in East Asia; Toward a New Model of East Asian Economy Center for Southeast Asian Studies, Kyoto University.

White, G., \& Goodman, R. (1998). Welfare Orientalism and the in Search for An East Asian Welfare Model. In Roger, G., White, G.,\& Kwon, H. J. (Eds.), The East Asian Welfare Model: Welfare Orientalism and the State. London: Routledge. 